\title{
Kontekstualisasi Roma 12:2 dalam Keniscayaan Dunia Digital
}

\author{
Eny Suprihatin ${ }^{1)^{*}}$ \\ 1) STAK Terpadu PESAT, Indonesia \\ *) E-mail: prihatineny67@yahoo.co.id
}

Diterima: 23 Juli 2020

Direvisi: 01 Maret 2021

Disetujui: 01 Juni 2021

\begin{abstract}
Abstrak
Dunia berkembang sangat cepat. Berbagai media sosial hadir dan bersaing untuk memenuhi kebutuhan dasar manusia, yaitu cinta dan harga diri (Abraham Maslow). Penelitian ini menggunakan studi kepustakaan dengan mengadakan survei terhadap data yang sudah ada dan menggali teori-teori yang telah berkembang sehubungan dengan kebutuhan dasar manusia dan media sosial, serta analisis teks terhadap Roma 12:2. Tujuan penelitian ini sebagai kontekstualisasi Roma 12:2 dalam memberikan rambu-rambu bagi orang Kristen yang mengaktualisasikan diri di media sosial. Dari hasil pembahasan ditarik kesimpulan bahwa kontekstualisasi Roma 12:2 dalam dunia digital: Pertama, menjadi pertimbangan moral dalam bermedia sosial yaitu tidak serupa dengan dunia. Kedua, sebagai pertimbangan mental. Orang Kristen memercayai dicipta segambar dan serupa dengan Allah. Sebagai orang yang telah mengalami pembaruan budi tidak perlu mencitrakan diri dengan cara salah dalam memenuhkan kebutuhan aktualisasi diri. Ketiga, mendorong perubahan motivasi dalam bermedia sosial. Orang percaya menjadikan apa yang baik, berkenan dan sempurna sebagai motivasi dalam bermedia sosial. Keempat, menjadi pertimbangan etika dalam mengaktualisasikan diri di dunia digital. Dalam konteks saat ini, dunia digital dan media sosial adalah suatu keharusan. Roma 12:2 memberikan teguran keras: "Jangan menjadi seperti dunia." Orang Kristen memang hidup di dunia, tetapi perilaku dunia tidak boleh memasuki
\end{abstract}


kehidupannya. Orang Kristen yang matang tahu memilih dan berbuat baik, yang menyenangkan Allah dan sempurna.

Kata-Kata Kunci: Dunia Digital; Kontekstualisasi; Media Sosial; Roma 12: 2.

\section{Abstract}

The world is developing very fast. Various social media exist and compete to meet basic human needs, namely love and self-esteem (Abraham Maslow). This study uses a literature study by conducting a survey of existing data and exploring the theories that have developed in relation to basic human needs and social media, as well as text analysis of Romans 12: 2. The purpose of this study is to contextualize Romans 12:2 in providing signs for Christians who selfactualize on social media. From the results of the discussion, it was concluded that the contextualization of Romans 12: 2 in the digital world: First, it becomes a moral consideration in social media, which is not the same as the world. Second, as a mental consideration. Christians believe they are created in the image and likeness of God. As a person who has experienced a renewal of mind, there is no need to image himself in the wrong way in fulfilling the need for selfactualization. Third, encourage changes in motivation in social media. Believers make what is good, pleasurable and perfect as motivation in social media. Fourth, it is an ethical consideration in self-actualizing in the digital world. In today's context, the digital world and social media are a must. Romans 12:2 gives a strong rebuke: "Do not be like the world." Christians do live in the world, but worldly behavior should not enter their lives. Mature Christians know to choose and do good, which pleases God and is perfect.

Keywords: Contextualization; Digital World; Romans 12: 2; Social Media.

\section{Pendahuluan}

Dunia berkembang sangat cepat. Berbagai media sosial hadir dan berlomba memenuhi kebutuhan manusia. ${ }^{1}$ Artikel ini bermaksud mencoba memahami/menjelaskan motivasi manusia dalam menggunakan media sosial, mengacu pada teori hierarki kebutuhan yang dikumandangkan oleh Abraham Maslow. Media sosial pada dasarnya tidak buruk. Namun terkadang para pengguna media sosial menjadikannya terlihat buruk. Media sosial menjadi

${ }^{1}$ Kristian Badai, Kaleb Djeremod, and Frets Keriapy, "Penginjilan Sebagai Upaya Meneguhkan Keyakinan Keselamatan Anak," Harvester: Jurnal Teologi dan Kepemimpinan Kristen 5, no. 2 (2020): 120-134. 
salah satu cara dan alternatif mengekspresikan eksistensi penggunanya. ${ }^{2}$ Namun tentu saja batasan-batasan diperlukan dalam menentukan ekspresi-ekspresi tersebut. ${ }^{3}$ Berikut beberapa kasus yang berkaitan dengan penyalahgunaan media sosial dan salah dalam mengekspresikan diri dan pemikiran melalui media sosial. Pertama, tujuh anggota sindikat penipuan melalui media sosial, ditangkap oleh tim Satreskrim Polres Bandung. Modus penipuan dengan cara berkenalan menggunakan akun dan foto palsu di media sosial. Korban rata-rata perempuan. ${ }^{4}$ Kedua, kasus cyberbullying marak terjadi di kalangan remaja. Cyberbullying adalah kekerasan berupa perlakuan yang tidak menyenangkan, menekan, menyakiti yang dilakukan perorangan atau kelompok kepada seseorang melalui telepon seluler, media sosial, komputer, dan alat komunikasi elektronik lainnya secara berulang, yang membuat korban tertekan bahkan bisa mengakhiri hidupnya. ${ }^{5}$ Ketiga, kasus yang berhubungan dengan penyebaran kabar bohong/hoax dan ujaran kebencian. Seorang pemuda 18 tahun berinisial MPA ditangkap Maret 2018 karena menyebarkan berita bohong dan ujaran kebencian tentang akan adanya penyerangan terhadap ulama. ${ }^{6}$ Ada peperangan nyata antara kebutuhan dasar dan moralitas serta spiritualitas. Orang Kristen dapat memilih untuk terpenuhi kebutuhan dasarnya tanpa kehilangan moralitas dan spiritualitasnya. ${ }^{7}$ Namun dapat juga larut menjadi serupa dengan dunia dalam hal ini. Paulus dalam suratnya kepada jemaat di Roma 12:2 memberi teguran keras, "Jangan serupa dengan dunia ini."

Dalam konteks terkini, dunia digital dan media sosial adalah sebuah keniscayaan. ${ }^{8}$ Bagaimana harus bersikap? Aktualisasi Roma 12:2 bukan lagi sebuah utopia. Orang Kristen harus menentukan pilihan. Eksis dengan

\footnotetext{
${ }^{2}$ Rizka Estiyani, Lisnawati Ruhaena, and others, "Ekspresi Diri Melalui Media Sosial Dan Maknanya Pada Remaja SMP” (Universitas Muhammadiyah Surakarta, 2018), 1

${ }^{3}$ Fiona Almira Pohan and Hairul Anwar Dalimunthe, "Hubungan Intimate Friendship Dengan Self-Disclosure Pada Mahasiswa Psikologi Pengguna Media Sosial Facebook," Jurnal Diversita 3, no. 2 (2017): 15-24.

${ }^{4}$ Agus Darmawan, Muhyani Muhyani, and Salati Asmahasanah, "Hubungan Pola Asuh Orang Tua Dan Guru Dengan Penyalahgunaan Media Sosial Di Man 1 Kota Bogor," e-Jurnal Mitra Pendidikan 3, no. 11 (2019): 1357-1369.

5 Machsun Rifauddin, "Fenomena Cyberbullying Pada Remaja," Jurnal Ilmu Perpustakaan, Informasi, dan Kearsipan Khizanah Al-Hikmah 4, no. 1 (2016): 35-44.

${ }^{6}$ Deisti Glorya Christina Tani and Nani Mediatati, "Tingkat Kesadaran Hukum Peserta Didik Dalam Menggunakan Media Sosial," Journal of Education Technology 4, no. 1 (2020): $17-21$.

${ }^{7}$ Yanti Dwi Astuti, "Peperangan Generasi Digital Natives Melawan Digital Hoax Melalui Kompetisi Kreatif," Informasi 47, no. 2 (2017): 229.

${ }^{8}$ Topan Setiawan, Yuni Kurniawati, and Edy Saputro, "Komunikasi Krisis Di Era Digital," Jurnal Ekonomi, Sosial \& Humaniora 1, No. 02 (2019): 50-61.
} 
menafikan kekudusan atau eksis dengan tetap menjaga kekudusan. ${ }^{9}$ Permasalahan dalam penelitian ini dirumuskan sebagai berikut: pertama, bagaimana media sosial dalam konteks hierarki kebutuhan menurut Abraham Maslow? Kedua, bagaimana kontektualisasi Roma 12:2 dalam keniscayaan dunia digital? Tujuan penelitian ini, pertama mendeskripsikan media sosial dalam konteks hierarki kebutuhan menurut Abraham Maslow. Kedua, mendeskripsikan kontektualisasi Roma 12:2 dalam keniscayaan dunia digital. Kelebihan artikel ini adalah menemukan kontekstualisasi antara pengajaran pembaruan budi di Roma 12:2 terkait pilihan untuk tidak menjadi serupa dengan dunia di tengah kebutuhan manusia seperti dalam hierarki kebutuhan manusia Abraham Maslow dalam keniscayaan dunia digital.

\section{Metode Penelitian}

Metode penelitian yang digunakan dalam tulisan ini adalah Studi Pustaka atau studi literatur. ${ }^{10}$ Menurut Darmayanti, Studi Kepustakaan adalah teknik pengumpulan data dengan mengadakan studi penelaahan terhadap buku-buku, literatur-literatur, jurnal. ${ }^{11}$ Sementara itu M. Nazir menyebutkan selain hal di atas, sumber diperoleh juga dari catatan-catatan dan laporan-laporan yang ada hubungannnya dengan masalah yang dipecahkan. ${ }^{12}$ Penelitian ini menggunakan sumber-sumber teks dari buku, literatur, serta jurnal yang relevan untuk memecahkan masalah yang ditetapkan dalam judul, untuk menemukan kontekstualisasi pembaruan budi di Roma 12:2 dalam keniscayaan dunia digital. ${ }^{13}$ Penelitian "Kontekstualisasi Roma 12:2 dalam Keniscayaan Dunia Digital" memiliki dua variabel yaitu Kontekstualisasi Roma 12:2 dan keniscayaan dunia digital. Kontekstualisasi Roma 12:2 ditetapkan sebagai variabel satu atau variabel $X$. Sedangkan keniscayaan dunia digital ditetapkan sebagai variabel dua atau variabel Y. Hubungan kedua variabel dapat dijelaskan sebagai berikut: penetapan variabel $X$ untuk mengetahui sejauh mana kontekstualisasi pembaruan budi yang terdapat di teks Roma 12:2 dalam

${ }^{9}$ Daniel Ronda, "Kepemimpinan Kristen Di Era Disrupsi Teknologi," Evangelikal: Jurnal Teologi Injili dan Pembinaan Warga Jemaat (2019).

${ }^{10}$ Nurni Amiroh Dwi Isma Ardana and Budi Purwoko, "Studi Kepustakaan Penerapan Konseling Naratif Dalam Lingkup Pendidikan,” Jurnal BK Unesa 8, no. 2 (2018).

${ }^{11}$ Kusumasari Kartika Hima Darmayanti, Farida Kurniawati, and Dominikus David Biondi Situmorang, "Bullying Di Sekolah: Pengertian, Dampak, Pembagian Dan Cara Menanggulanginya," Pedagogia 17, no. 1 (2019): 55-66.

${ }^{12}$ M Nazir, Metode Penelitian (Bogor: Ghalia Indonesia, 2009), 111

${ }^{13}$ Dwitri Pilendia, "Pemanfaatan Adobe Flash Sebagai Dasar Pengembangan Bahan Ajar Fisika: Studi Literatur," Jurnal Tunas Pendidikan 2, no. 2 (2020): 1-10. 
keniscayaan dunia digital, yang ditetapkan sebagai variabel Y. Sesuai dengan metode penelitian yang digunakan yaitu Studi Kepustakaan, maka pengumpulan data dilakukan dengan telaah buku, literatur dan catatan yang berhubungan dengan kajian. ${ }^{14}$ Selain studi literatur, untuk mendapatkan pemahaman dari Roma 12:2 dan mengkontekstualisasikannya dalam kaitan dengan penggunaan media sosial/dunia digital, digunakan metode analisis teks. ${ }^{15}$ Hasil dari penelaahan teks digunakan untuk melihat kontekstualisasi variabel $\mathrm{X}$ dalam Variabel Y. Kemudian ditarik kesimpulan bagaimana kontekstualisasi Roma 12:2 dalam keniscayaan dunia digital.

\section{Pembahasan dan Hasil \\ Media Sosial: Selayang Pandang}

Pemanfaatan aplikasi paling besar di era internet adalah aplikasi media sosial. Dua kata pembentuk frasa media sosial, adalah: media dan sosial. Kamus Besar Bahasa Indonesia mendefinisikan media sebagai alat atau sarana komunikasi. Sosial adalah berkenaan dengan masyarakat. ${ }^{16}$ Berdasar pengertian di atas, frasa Media Sosial dapat diartikan sebagai alat atau sarana berkomunikasi dengan masyarakat. Dalam dunia digital media sosial adalah aplikasi berbasis internet yang memungkinkan penggunanya berinteraksi satu dengan yang lain dengan membuat informasi dan membagikannya serta menerima informasi dari pengguna lainnya. ${ }^{17}$ Media sosial adalah sebuah media daring, dengan para penggunanya bisa dengan mudah berpartisipasi, berbagi, dan menciptakan isi. Lingkup media sosial meliputi blog, jejaring sosial berupa twitter, facebook, wiki, forum dan dunia virtual. ${ }^{18} \mathrm{Blog}$, jejaring sosial dan wiki merupakan bentuk media sosial yang paling umum digunakan oleh masyarakat di seluruh dunia. Berdasarkan beberapa definisi di atas dapat disimpulkan bahwa media sosial adalah sebuah sarana komunikasi masa kini berbasis internet yang memungkinkan penggunanya memberi dan menerima informasi dengan cepat kepada sesama pengguna dalam berbagai bentuk. Seperti blog, facebook,

${ }^{14}$ Evita Roesnilam Syafitri and Wiryo Nuryono, "Studi Kepustakaan Teori Konseling 'Dialectical Behavior Therapy'. Jurnal BK Unesa 11, no. 1 (2020).

${ }^{15}$ Sonny Eli Zaluchu, "Pola Hermenetik Sastra Hikmat Orang Ibrani," Evangelikal 3, no. 1 (2019): 21-29, https://journal.sttsimpson.ac.id/index.php/EJTI/article/view/123.

16 Departemen pendidikan Nasional, Kamus Besar Bahasa Indonesia Pusat Bahasa,Ed.IV, IV. (Jakarta: PT. Gramedia Pustaka Utama, 2008).

${ }^{17}$ Kominfo Siber Kreasi Literasi Digital, Media Sosial Pdf (Jakarta, n.d.), 4-5

${ }^{18}$ Irla Yulia, "Optimalisasi Penggunaan Media Sosial Dalam Pemasaran Sosial Dan Komunikasi Perubahan Perilaku (Suatu Pendekatan Studi Literature Review)," HEARTY: Jurnal Kesehatan Masyarakat 6, no. 2 (2018). 
youtube, twitter dan sebagainya. Semua dengan satu tujuan aktualisasi diri yang lebih luas.

Beberapa jenis media sosial yang banyak dikenal masyarakat luas di Indonesia adalah: Facebook, Twitter, Youtube, Instagram, blog, dan Google Plus. ${ }^{19}$ Media-media ini tidak hanya digunakan sebagai sarana berbagi informasi dan inspirasi, tetapi juga dapat dipakai untuk pencitraan diri (personal branding), ekspresi diri (self expression), hingga arena "curhat", sumpah serapah, bahkan menebar hoax..$^{20}$ Penggunaan media sosial yang terbaik adalah untuk memberi informasi dan inspirasi. Adapun sifat atau karakteristik media sosial dalam hal pesan adalah: tidak hanya dapat ditujukan pada seseorang saja tetapi bisa ke banyak orang sekaligus. ${ }^{21}$ Seperti SMS atau melalui internet. Dalam waktu yang singkat dan sama orang-orang di berbagai belahan duniapun dapat membacanya. Pesan dapat disampaikan bebas tanpa adanya yang disebut gatekeeper. ${ }^{22}$ Tidak ada pintu gerbang penyaring pesan tersebut. Pesan diterima cenderung lebih cepat dari media yang lain. Dari sisi penerima pesan, mereka dapat menentukan waktu interaksi. ${ }^{23}$

Menurut data Badan Pusat Statistik dan Asosiasi Jasa Pengguna Internet Indonesia sampai akhir 2013, seperti yang dikutip oleh Adiarsi, jumlah pengguna internet di Indonesia mengalami pertumbuhan 13\% atau 71.19 juta orang. ${ }^{24}$ Dari 143 juta jiwa anak muda, 54\% sudah menggunakan internet. Artinya lebih dari separuh anak-anak muda menggunakan media sosial. Apalagi untuk generasi $\mathrm{Y}, \mathrm{Z}$ dan Alfa, yang adalah digital native. ${ }^{25}$ Mengutip pernyataan Lucy, Indonesia dengan total penduduk 265,4 juta jiwa, 50\% adalah pengguna internet. Dari $50 \%$ tersebut setengahnya adalah digital native. ${ }^{26}$ Penggunaan

${ }^{19}$ Pamela Felita et al., "Pemakaian Media Sosial Dan Self Concept Pada Remaja," Manasa-old 5, no. 1 (2016): 30-41.

${ }^{20}$ Dedi Rianto Rahadi, "Perilaku Pengguna Dan Informasi Hoax Di Media Sosial," Jurnal Manajemen dan Kewirausahaan 5, no. 1 (2017): 58-70.

${ }^{21}$ Yuni Tresnawati and Kurniawan Prasetyo, "Pemetaan Konten Promosi Digital Bisnis Kuliner Kika's Catering Di Media Sosial,” PRofesi Humas 3, no. 1 (2018): 102-119.

${ }^{22}$ Nela Widiastuti, "Berita Viral Di Media Sosial Sebagai Sumber Informasi Media Massa Konvensional," Journal Digital Media \& Relationship 1, no. 1 (2019): 23-30.

23 Ahmad Sukrillah, Ike Atikah Ratnamulyani, and Ali Alamsyah Kusumadinata, "Pemanfaatan Media Sosial Melalui Whatsapp Group Fei Sebagai Sarana Komunikasi," Jurnal Komunikatio 3, no. 2 (2018).

${ }^{24}$ Gracia Rachmi Adiarsi, Yolanda Stellarosa, and Martha Warta Silaban, "Literasi Media Internet Di Kalangan Mahasiswa," Humaniora 6, no. 4 (2015): 470-482.

${ }^{25}$ Ranny Rastati, "Media Literasi Bagi Digital Natives: Perspektif Generasi Z Di Jakarta," Kwangsan 6, no. 1 (2018): 2.

${ }^{26}$ Lucy Pujasari Supratman, "Penggunaan Media Sosial Oleh Digital Native" (2018), 1 
internet bermacam-macam, seperti: memasarkan dan mempromosikan produk dan jasa. Biasanya menggunakan jaringan media sosial facebook, twitter, dan yang lain. Membangun komunikasi dalam rangka membentuk image atau branding. Data segmen pengguna internet dapat digambarkan sebagai berikut: 82,2 juta orang mengunjungi online shop, 45,3 juta mengunjungi konten komersil bisnis personal, 1,5 juta untuk hal yang lain. Ada tiga Media Sosial yang banyak dikunjungi: facebook dengan pengguna 71,6 juta, Instagram 19,9 juta dan youtube 14,5 juta. ${ }^{27}$ Pengguna terbesar adalah rentang usia 25-44 tahun, usia dewasa. Penggunaan Facebook mendominasi percakapan grup di samping WhatsApp yang menggantikan SMS karena lebih komunikatif. Karena di usia ini karir dan profesi makin matang maka dorongan untuk personal branding makin menguat. Oleh karena itu LinkedIn menjadi pilihan wajib berikutnya.

\section{Media Sosial Dalam Konteks Hierarki Kebutuhan Menurut Abraham Maslow}

Manusia adalah ciptaan unik yang memiliki banyak kebutuhan dasar. Abraham Maslow seperti yang dikutip oleh Boeree, mengetengahkan sebuah teori tentang kebutuhan dasar manusia yang disebut Hierrarki Kebutuhan. ${ }^{28}$ Teori ini telah dikembangkan dalam berbagai bidang baik psikologi, bisnis, pendidikan dan lain-lain. Bentuk piramida dalam Hierarki Kebutuhan Maslow membantu kita untuk membaca faktor-faktor yang memotivasi perilaku manusia. Teori yang dikemukakan Maslow ini untuk mengkritisi teori Psikoanalisa Freud dan Behavioristik..$^{29}$ Freud menyatakan bahwa alam bawah sadar (id dan superego) adalah sumber motivasi dan dorongan terhadap hasrat seseorang, baik yang sederhana (makan, seks) maupun kreativitas (karya). ${ }^{30}$ Sementara itu dalam teori Behavioristik, manusia seperti dikatakan oleh Bandura pada dasarnya bersifat mekanistik, merespon lingkungan dengan kontrol terbatas. Jadi perilaku manusia lebih didorong oleh respon terhadap lingkungan. ${ }^{31}$

${ }^{27}$ Budi Susilo, "Pemasaran Digital: Segmentasi Demografi Pengguna Media Sosial Di Kota Pontianak," Jurnal Eksplora Informatika 8, no. 1 (2018): 69-79.

${ }^{28}$ C.George Boeree, Personality Theories, Melacak Kepribadian Anda Bersama Psikolog Dunia (Yogyakarta: Prismasophie, 2004), 278

29 Novi Irwan Nahar, "Penerapan Teori Belajar Behavioristik Dalam Proses Pembelajaran,” NUSANTARA: Jurnal Ilmu Pengetahuan Sosial 1, no. 1 (2016).

${ }^{30}$ Hengki Wijaya and I Putu Ayub Darmawan, "Optimalisasi Superego Dalam Teori Psikoanalisis Sigmund Freud Untuk Pendidikan Karakter” (2019), 2

${ }^{31}$ Sigit Sanyata, "Teori Dan Aplikasi Pendekatan Behavioristik Dalam Konseling," Jurnal Paradigma 14, no. 7 (2012): 1-11. 
Lalu bagaimana hubungannya Piramida Maslow dengan media sosial? Menurut teori ini kebutuhan dasar yang paling luas adalah kebutuhan fisiologis. ${ }^{32}$ Kebutuhan ini mencakup kebutuhan oksigen, air, protein, garam, gula, mineral, vitamin, bergerak, istirahat, tidur dan seks yang sifatnya sangat individual. Dengan kata lain kebutuhan fisiologis bukanlah kebutuhan sosial. Secara alamiah manusia akan berusaha untuk meraihnya meskipun tidak hidup dalam kelompok sosial. Kedua, kebutuhan akan rasa aman. Setelah lapis pertama dipenuhi maka lapis kedua muncul. Manusia membutuhkan rasa aman, stabil dan terlindung. Kebutuhan akan rasa aman diwujudkan dalam bentuk: tinggal saling berdekatan dengan tetangga, memiliki asuransi, punya dana pensiun. ${ }^{33}$ Kebutuhan di tingkat kedua dari Piramida Maslow merupakan kebutuhan sosial dalam tingkatan yang pertama. Ketika terjadi resesi ekonomi pada tahun 2007-2009, pelaku media sosial melakukan pergerakan masif dengan menggunakan aplikasi LinkedIn; di mana setiap orang dapat mencari pekerjaan dan menawarkan diri kepada pencari kerja. Ketiga, kebutuhan cinta dan rindu. Jika dua lapis, kebutuhan fisiologis dan rasa aman, terpenuhi maka akan muncul kebutuhan lapis ketiga. ${ }^{34}$

Manusia mulai membutuhkan teman, kekasih, anak, dan hubungan berdasarkan perasaan. Secara negatif manusia takut dan kuatir mengalami kesepian dan kesendirian. Maka timbul keinginan menikah, punya keluarga, dan menjadi bagian masyarakat. Dalam taraf ini media sosial menjadi sarana yang dapat digunakan untuk memenuhi cinta dan rindu ini ke dalam kelompok dan media sosial yang tepat menampung ini adalah Facebook. Orang-orang mulai mengkoneksikan diri karena persamaan-persamaan seperti: asal usul (keluarga, sekolah), hobi dan minat, serta pertemanan baru. Maka tidak salah jika di 2018 Facebook tetap merajai media sosial dengan lebih dari dua milyar pengguna di seluruh Dunia. Keempat, kebutuhan akan harga diri. Lapis keempat kebutuhan manusia ini menurut Maslow ada dua bentuk. Bentuk yang kuat dan yang lemah. Bentuk yang kuat termanifestasi dalam percaya diri, kompetensi, reputasi, kesuksesan, independensi dan kebebasan. Bentuk yang lemah adalah

${ }^{32}$ Elisha Orcarus Allasso and others, "Aktualisasi Diri Ki Seno Nugroho: Tinjauan Pemenuhan Kebutuhan Dalam Teori Motivasi Abraham H. Maslow” (Institut Seni Indonesia Yogyakarta, 2016). 279

${ }^{33}$ Boeree, Personality Theories, Melacak Kepribadian Anda Bersama Psikolog Dunia,

${ }^{34}$ Novita Indriani Rorong and Dicky Dominggus, "Budaya Kekerasan Dalam Media Elektronik Ditinjau Dari Sudut Pandang Etika Kristen," FIDEI: Jurnal Teologi Sistematika dan Praktika 3, no. 1 (2020): 88-109. 
kebutuhan manusia untuk dihargai orang lain, status, kemuliaan, kehormatan, perhatian, reputasi, apresiasi bahkan dominasi. Bentuk yang pertama (yang kuat) lebih kuat dari yang kedua. Sekali manusia mendapatkan, tidak akan mudah melepaskannya dibanding dengan kebutuhan untuk dihargai orang lain. Jika kebutuhan lapis keempat tidak terpenuhi akan muncul rasa rendah diri dan kompleks inferioritas. ${ }^{35}$

Dalam tingkatan ini karakteristik pengguna media sosial adalah kepercayaan diri yang tinggi, untuk menunjukkan siapa dirinya, bahkan cenderung pamer, dan menuntut penghargaan dari orang lain. Youtube dan Instagram saat ini sangat akrab di kalangan orang muda, namun tweeter juga menjadi media alternatif untuk mengakomodasi kebutuhan tingkat empat ini. Tingkat terakhir dari kebutuhan manusia dalam hierarki Maslow adalah kebutuhan aktualisasi diri. Maslow menyebutnya sebagai B. Needs (being needs) kebutuhan-kebutuhan untuk ada. ${ }^{36}$ Kebutuhan ini meliputi hasrat untuk terus menerus mewujudkan potensi diri, keinginan untuk menjadi apa yang dia bisa, menjadi "dia" yang sebenarnya. Mereka ini memiliki kualitas dan karakter khusus yaitu: pertama, berorientasi pada realita, yaitu bisa membedakan antara yang pura-pura dengan asli. Kedua, berorientasi pada persoalan, yaitu memandang persoalan hidup sebagai sesuatu yang harus dicari jalan keluarnya. Ketiga, memiliki persepsi yang berbeda-beda tentang apa yang menjadi alat dan yang menjadi tujuan. Proses atau perjuangan lebih penting daripada tujuan. ${ }^{37}$ Tinggal dalam kesunyian dan nyaman dalam kesendirian, bagi mereka yang mencapai taraf ini, telah melahirkan kemampuan menerima diri sendiri dan orang lain, demokratis, memiliki kualitas persaudaraan, kepekaan sosial, simpati dan perikemanusiaan dilengkapi dengan etika yang kuat. Orang yang dapat mengaktualisasikan diri memiliki kesegaran apresiasi dalam memandang segala sesuatu, termasuk yang remeh dengan rasa takjub. Sehingga muncul kemampuan untuk selalu kreatif, inventif dan orisinal. Dalam tataran ini media sosial berbasis blog seperti Blogspot menjadi wadah bagi orang-orang yang ingin memenuhi kebutuhan mereka yaitu aktualisasi diri, yang tertuang dalam tulisan pemikiran yang bermutu.

35 Denok Sunarsi, "Analisis Motivasi Kerja Tenaga Pendidik Sukarela Pada Pusat Kegiatan Belajar Masyarakat (PKBM) Bimasda Kota Tangerang Selatan," Kreatif: Jurnal Ilmiah Prodi Manajemen Universitas Pamulang 6, no. 2 (2018): 53-65.

${ }^{36}$ Boeree, Personality Theories, Melacak Kepribadian Anda Bersama Psikolog Dunia, 279 2016), 219

37 Alwisol, Psikologi Kepribadian (Malang: Penerbitan Universitas Muhammadiyah, 


\section{Analisis Roma 12:2}

Pada saat Paulus menulis surat kepada orang-orang Kristen di Roma, Roma adalah pusat dunia saat itu. Sebagai kota metropolitan, Roma bukan saja menjadi pusat kekaisaran tetapi juga menjadi pusat agama dan budaya. Kehidupan Kristen yang merupakan sambutan atas kemurahan Allah terhadap dirinya berhadapan dengan kebebasan tatanan kehidupan pada masa itu, baik dalam hidup beragama dan berbudaya. ${ }^{38}$ Standar kekudusan yang dituntut Tuhan berbenturan dengan kebiasaan hidup bebas yang berlaku. Dalam hal berpakaian eksotis, makan makanan yang haram, percakapan yang tidak membangun. Terjadi pemutar balikan berita dan pengajaran Paulus. Karena itu Paulus menekankan nasehatnya dalam Roma 12:1 supaya jemaat memersembahkan tubuhnya sebagai persembahan yang hidup, yang kudus dan yang berkenan kepada Allah sebagai ibadahnya yang sejati. Paulus mengingatkan pada jemaat waktu itu bahwa "tubuh" (=kehidupan) bukan milik mereka sendiri, tetapi milik Allah yang harus dipersembahkan dalam keadaan kudus. Kekudusan bukan bahan jadi, tetapi pengudusan. Orang Kristen harus berupaya terus hidup semakin sesuai dengan kehendak DIA yang menjadi pemiliknya (tuannya) atau pengudusan progresif yang merupakan bukti seorang Kristen bertumbuh dewasa dalam iman. ${ }^{39}$

Jaffray mengatakan bahwa, "Roma 12 merupakan rangkaian kelima, yaitu rangkaian yang seakan-akan merupakan puncak dari segala pengajaran Paulus." Orang Kristen tidak cukup hanya memersembahkan harta, pekerjaan, dan segala sesuatunya, jika hidupnya tidak dipersembahkan sebagai persembahan yang hidup dan kudus, semua sia-sia bahkan dibenci Tuhan. ${ }^{40}$ Orang Kristen memang hidup di dunia, tetapi diingatkan oleh Paulus tata laku dunia tidak boleh memasuki hidupnya. Beberapa hal yang diingatkan Paulus adalah: Pertama, sadar bahwa sistem dunia ini jahat dan ada di bawah pemerintahan iblis. Kedua, harus tegas terhadap segala cara yang berlaku dan populer dari roh dunia sambil memberitakan kebenaran kekal dan standar kebenaran Firman Allah. Ketiga, harus membenci kejahatan dan mengasihi yang benar. Keempat, pikiran harus

\footnotetext{
${ }^{38}$ Th.Van Den End, Tafsir Alkitab Surat Roma (Jakarta: BPK Gunung Mulia, 2003), 3

${ }^{39}$ Dicky Dominggus, "Efektivitas Pelaksanaan Ibadah Daring Ditinjau Dari Roma 12: 12," Sanctum Domine: Jurnal Teologi 10, no. 1 (2020): 35-48.

${ }^{40}$ R.A. Jaffray, Tafsiran Surat Roma (Bandung: Yayasan Kalam Hidup, 2007), 213
} 
diselaraskan dengan cara Allah. ${ }^{41}$ Ditegaskan oleh Paulus bahwa dunia jangan dijadikan teladan berperilaku.

Senada dengan pernyataan di atas, End mengatakan bahwa orang Kristen tidak boleh lagi membiarkan pola hidupnya ditentukan oleh dunia. ${ }^{42}$ Menurut terjemahan harafiah: "Jangan lagi biarkan dirimu menjadi sepola dengan dunia ini." Dunia merupakan terjemahan $\alpha i \tilde{\omega} v$ (aiôn) yang berarti "masa yang sangat panjang," "masa hidup dunia." 43 aĩ̃v (aiôn) adalah bentuk umum dari kata

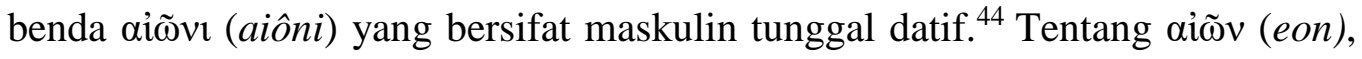
dalam Alkitab ditemukan ada dua "eon" yang berakar dalam apokaliptik Yahudi. Pertama, eon yang sedang berlangsung sekarang, yang lain akan datang. Kedua, yang satu dikuasai dosa, kerusakan, kematian, yang lain ditandai oleh kesempurnaan, kehidupan. ${ }^{45}$ Dalam Roma 12: 2 tambahan "ini" menunjukkan bahwa "eon" dipakai dengan arti "Dunia yang dikuasai dosa dan ketidaksempurnaan." Jadi, kata-kata "Janganlah kamu menjadi serupa dengan dunia ini" tidak boleh ditafsirkan seakan-akan orang percaya diajak menjauhi dunia dalam arti jasmani. Misalnya menjadi pertapa. ${ }^{46}$

Dari sisi positif, anjuran Paulus berbunyi: "Berubahlah oleh pembaruan budimu." Kata Yunani tõ̃ voós (tounoos) merupakan kata benda tunggal genetif, diterjemahkan sebagai "budi" atau "akal budi" atau "pikiran." Pembaruan voós (noos) adalah syarat untuk dapat mengenal dan melakukan kehendak Allah. Apa yang diyakini oleh voó memengaruhi behavior (perilaku) seseorang. ${ }^{47}$ Roma 14: 1-8 ada tertulis: Terimalah orang...yang seorang yakin, bahwa ia boleh makan segala jenis makanan, tetapi orang yang lemah imannya hanya makan sayur-sayuran saja. Siapa yang makan, janganlah menghina orang yang tidak makan, dan siapa yang tidak makan, janganlah menghakimi orang yang makan, sebab Allah telah menerima orang itu..." Firman Tuhan di atas memberi gambaran jelas apa yang dapat dipilih oleh seseorang untuk dilakukan atau tidak dilakukan. Jadi, yang

${ }^{41}$ Alkitab Penuntun Hidup Berkelimpahan (Malang: Gandum Mas dan LAI, 2009), 18641865

${ }^{42}$ End, Tafsir Alkitab Surat Roma, 657

${ }^{43}$ End, Tafsir Alkitab Surat Roma, 658

${ }^{44}$ Hasan Sutanto, Perjanjian Baru Interlinear Yunani-Indonesia Dan Konkordansi Perjanian Baru (PBIK), I. (Jakarta: LAI, 2006), 862

${ }^{45}$ End, Tafsir Alkitab Surat Roma, 657

${ }^{46}$ End, Tafsir Alkitab Surat Roma, 657

${ }^{47}$ Sutanto, Perjanjian Baru Interlinear Yunani-Indonesia Dan Konkordansi Perjanjian Baru (PBIK), 862 
menjadi tujuan adalah perubahan kelakuan manusia bukan perubahan pikirannya saja. $^{48}$

Paulus menggunakan kata voó (noos) dengan cara khas Ibrani. Paulus tidak memikirkan sebagai bagian terpisah dari diri manusia. Sesuai dengan pemikiran Ibrani, Paulus mengartikan sebagai manusia yang utuh yang berakal budi, yang mampu untuk mengerti. Nous menjangkau seluruh kegiatan mental manusia, bukan hanya perenungan saja. Pembaruan voó (noos) - akal budi akan menghasilkan hidup kudus. Dengan demikian pengalaman perubahan perilaku atau tindakan adalah hasil pembaruan budi. Terjadi perubahan dari yang tidak baik menjadi baik, dari perilaku negatif menjadi positif. Hanya voó (noos) yang mengakui Allahlah yang dapat berlaku positif. Apabila voós (noos) tidak

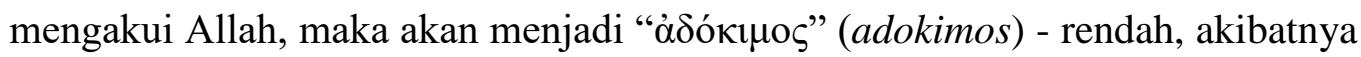
timbul tingkah laku yang tidak pantas. ${ }^{49}$ Dikatakan dalam Roma 1: 28, "Dan karena mereka tidak merasa perlu untuk mengakui Allah, maka Allah menyerahkan mereka kepada pikiran-pikiran yang terkutuk, sehingga mereka melakukan apa yang tidak pantas."

Menolak untuk mengakui Allah menimbulkan pengaruh yang merugikan. Akal budi menjadi lebih sulit menerima penyataan-penyataan Allah. Bagi orang percaya, akal budi diberi cahaya dan dapat dibarui. Nous manusia harus disesuaikan dengan nous Allah. 1 Korintus 2: 12, "Siapakah yang dapat mengetahui pikiran Tuhan, sehingga ia dapat menasihati Dia?" Tetapi kami memiliki pikiran Kristus. ${ }^{50}$ Bagian kedua dari ayat di atas menyebut hasil pembaruan budi. Tujuannya ialah sehingga kamu dapat membedakan manakah

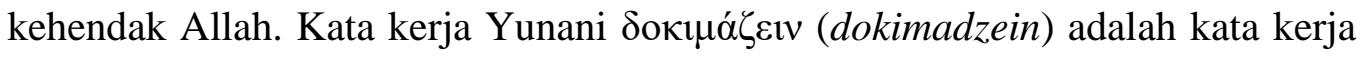
partisipel akusatif genetif yang berarti: menguji, memeriksa. Kehendak Allah tidak serta-merta jelas. Ada dua alasan, pertama: dalam hidup sehari-hari orang percaya diperhadapkan berbagai keadaan. Seringkali sulit untuk mengambil atau menentukan sikap. Dengan perkembangan teknologi yang serba canggih di segala bidang, orang Kristen tidak dapat begitu saja menentukan apakah boleh menggunakan. Perlu memertimbangkan masak-masak sebelum menentukan. ${ }^{51}$ Kedua, orang Kristen diajak untuk mengusahakan "budi" nya dalam mencari kehendak Allah. Alkitab bukan kitab hukum, yang menyajikan peraturan yang

${ }^{48}$ E. Chrisna Wijaya, "Kekhasan Eskatologi Paulus," FIDEI: Jurnal Teologi Sistematika dan Praktika 1, no. 1 (2018): 21-41.

${ }^{49}$ Donald Guthrie, Teologi Perjanjian Baru 1, 1st ed. (Jakarta: PT BPK Gunung Mulia, 1991), 173-174

${ }^{50}$ Ibid.

${ }^{51}$ End, Tafsir Alkitab Surat Roma, 659 
menunjukkan jalan kepada orang Kristen sekaligus mengikatnya. Setiap orang percaya dipanggil dan diperbolehkan memertimbangkan sendiri kehendak Allah. Apabila Kristus menjadi masuk dan pusat kehidupannya, barulah seseorang dapat menjadi orang baru. Pikirannya berbeda, karena pikiran Kristus ada di dalamnya. ${ }^{52}$

Pembaruan budi seperti nampak dalam Roma 12: 2 menandai pertobatan Kristen. Orang-orang percaya diperlengkapi dengan daya tanggap yang lebih tajam dari sebelumnya, yakni dapat membedakan manakah kehendak Allah, apa yang baik, yang berkenan kepada Allah, dan yang sempurna. Paulus merinci kehendak Allah dalam tiga hal: yang baik, yang berkenan kepada Allah, dan yang sempurna. Menurut Nygren, Roma 12: 2 merupakan pedoman paling mendasar mengenai etika Paulus (Alkitab Sabda). Orang Kristen tidak boleh menjadi serupa dengan dunia. Artinya hidupnya harus mengalami perubahan. Tidak lagi menjadi sama atau serupa dengan dunia. ${ }^{53}$ Ketika seseorang percaya kepada Yesus Kristus, mengalami kelahiran baru. Allah menginginkan terjadi perubahan atau transformasi dalam hidup setiap orang yang percaya kepadaNya. 2 Korintus 3:18 mengatakan: “...Dan karena kemuliaan itu datangnya dari Tuhan yang adalah Roh, maka kita diubah menjadi serupa dengan gambar-Nya, dalam kemuliaan yang semakin besar." Kata berubahlah dalam Roma 12: 2 berasal dari kata $\mu \varepsilon \tau \alpha \mu о \rho \varphi о \tilde{\sigma} \theta \varepsilon$ (metamorfousthe) yang merupakan bentuk pasif imperatif kata $\mu \varepsilon \tau \alpha \mu$ ó $\varphi \omega \sigma$ (metamorfoo) artinya berubah rupa. Pemakaian bentuk pasif untuk menunjukkan bahwa perubahan tersebut bukan usaha manusia melainkan dikerjakan atau karya Roh Kudus. Istilah menjadi serupa dan diubahkan dipakai sejajar. Akar katanya morphe, yang berarti suatu bentuk atau unsur pokok yang tidak berubah-ubah. ${ }^{54}$ Metamorfosa yang pertama terjadi pada saat orang mengalami kelahiran baru. Terjadi ketika seseorang percaya kepada Tuhan Yesus Kristus. Berlangsung seketika atau radikal yang dalam Soteriologi disebut dengan kata Yunani " $\pi \alpha \lambda \imath v \gamma \varepsilon v \varepsilon \sigma i ́ \alpha$ ” (palingenesia) artinya pembaruan, kelahiran baru, lahir baru, atau regenerasi. ${ }^{55}$

Secara hukum berpindahnya posisi dari manusia berdosa menjadi orang benar, dari musuh Allah menjadi anak Allah, dari penyembah berhala menjadi penyembah Allah yang Hidup. Paulus menyebut sebagai ciptaan baru.

${ }^{52}$ William Barclay, Pemahaman Alkitab Setiap Hari Surat Roma, Cetakan Ke. (Jakarta: BPK Gunung Mulia, 2003), 236

53 Asih Rachmani Endang Sumiwi, "Pembaharuan Pikiran Pengikut Kristus Menurut Roma 12: 2," Jurnal Teologi Berita Hidup 1, no. 1 (2018): 46-55.

${ }^{54}$ Barclay, Pemahaman Alkitab Setiap Hari Surat Roma, 235

${ }^{55}$ Ibid, 235 
" $\pi \alpha \lambda \iota v \gamma \varepsilon v \varepsilon \sigma i \alpha \underline{\alpha}$ " (palingenesia) hanya digunakan dua kali dalam Perjanjian Baru.

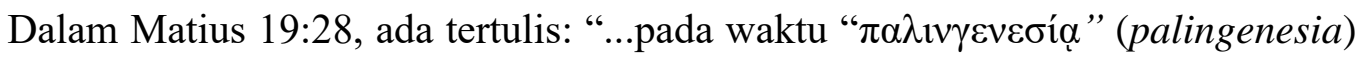
kata benda feminin tunggal datif- penciptaan kembali, apabila Anak Manusia bersemayam di takhta kemuliaan-Nya.... ${ }^{56} \mathrm{Hal}$ ini berkaitan dengan penyataan Kerajaan Allah, munculnya langit baru dan bumi baru yang akan dijadikan oleh Allah (2Ptr. 3:13; Why. 21). Berikutnya dalam Titus 3:5, “...bukan karena perbuatan baik yang telah kita lakukan, tetapi karena rahmat-Nya oleh

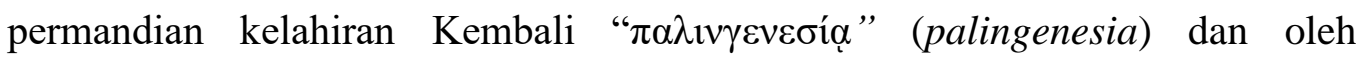
pembaruan yang dikerjakan oleh Roh Kudus."

Tuhan menghendaki semua orang yang percaya kepada-Nya, tidak hidup serupa dengan dunia sekalipun berada dalam dunia. Apabila tidak berjaga-jaga maka seorang Kristen dapat menjadi serupa dengan aion (dunia) ini. Roh Kudus disediakan bagi orang-orang yang mau hidup dengan aion baru. Dua hal yang dapat terjadi bagi seseorang yang percaya kepada Yesus Kristus. Pertama, akan berubah cara pandang dan gaya hidupnya menurut dunia yang baru sehingga tidak betah di dunia ini. Kedua, menyesuaikan dengan tata aturan dunia ini, sehingga tidak nampak perubahan pikir dan perilakunya. Jadi ada yang makin berkembang ke arah dunia yang akan datang, atau sebaliknya menjadi semakin serupa dengan dunia ini. Roma 12: 2 jelas menyerukan untuk tidak serupa dengan dunia. Hal ini dapat terjadi jika akal budi diperbarui Roh Kudus. Pada waktu seseorang percaya kepada Kristus, akal budinya tidak dihilangkan, tetapi dibarui. Paulus menekankan pentingnya pembaruan budi supaya tubuh ini dapat menyerah kepada panggilan yang lebih mulia.

Seiring perubahan budi maka perubahan perilaku terjadi. Perilaku disesuaikan dengan kehendak Tuhan, dan menolak untuk menjadi serupa dengan perilaku dunia. Hanya orang yang sudah dibarui pikiran atau budinya yang dapat mengerti kehendak Allah. Pembaruan budi akan menuntun seseorang kepada kepekaan akan Allah. Hal ini perlu proses dan latihan seumur hidup dalam kehidupan sehari-hari. Roh Kudus yang mengerjakan pembaruan tersebut akan menolong untuk mengerti apa yang dikehendaki Allah atas diri orang tersebut. Tuhan dapat menyatakan kehendak-Nya dalam berbagai cara. Seorang yang dibarui budinya tidak akan sembarang bertindak dan mengambil keputusan. Ia akan menguji apakah sesuatu atau perilaku itu sesuai dengan kehendak Allah

${ }^{56}$ Sutanto, Perjanjian Baru Interlinear Yunani-Indonesia Dan Konkordansi Perjanian Baru $(P B I K), 110$ 2014), 495

${ }^{57}$ B.J. Niftrik, G.C van, Boland, Dogmatika Masa Kini (Jakarta: BPK Gunung Mulia, 
atau tidak. Orang yang belum dibarui pikirannya tidak sanggup membedakan kehendak Tuhan. Sebaliknya, orang yang menyerahkan tubuhnya kepada Tuhan, yang pikirannya dibarui dapat mengerti kehendak tanpa ditolong orang lain.

Orang yang mengalami pembaruan budi dapat dengan sendirinya menguji apa yang seharusnya dilakukan atau tidak. Dalam Roma 12:2 juga termuat hal: yang baik, yang berkenan dan yang sempurna. Terjemahan yang baik dalam bahasa Yunani $\alpha \gamma \alpha \dot{\theta}$ os (agathos) dari kata sifat à $\gamma \alpha \theta \dot{o} v$ (agathon) neuter tunggal nominatif tidak bertingkat, mengambil bahasa Ibrani tov. Tov terutama menandakan sesuatu yang memberi kebahagiaan atau kepuasan yang memberi

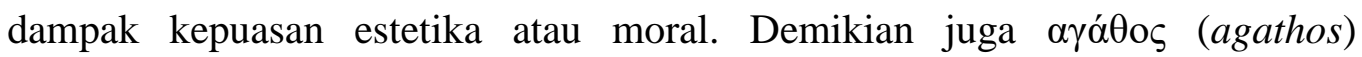
mengandung pengertian gagasan yang baik sebagai kualitas jasmani atau moral. Dalam kaitannya dengan kecenderungan jemaat Roma yang begitu rupa mengutamakan kebebasan dan tidak lagi mau terikat dengan aturan-aturan bagi kelakuannya, Paulus memberikan rincian untuk kehendak Allah. Bagi orang yang seperti tersebut di atas perlu dipentingkan bahwa melakukan kehendak Allah adalah melakukan yang baik.

Mencari yang baik berarti mencari Tuhan, sebab hanya Tuhan saja yang baik. Hanya Tuhan yang dapat memberikan jawaban pertanyaan apa yang baik itu. Jawaban Tuhan ada di Mikha 6: 8, "Hai manusia, telah diberitahukan kepadamu apa yang baik. Dan apa yang dituntut Tuhan dari padamu: selain berlaku adil, mencintai kesetiaan, dan hidup dengan rendah hati di hadapan Allahmu?" 58 Jika ditelusuri dari arti kata menurut pengertian Kamus Bahasa Indonesia, maka frasa yang baik berasal dari kata yang dan baik. Dapat dijelaskan sebagai berikut: Pertama, baik mengandung pengertian: elok, patut, teratur (apik, rapi), beres, tidak ada celanya. Kedua, berguna atau manjur, jika dikenakan tentang obat. Ketiga, tidak jahat, bicara mengenai kelakuan, budi pekerti, keturunan bukan orang sembarangan. Keempat, selayaknya, sepatutnya. 59

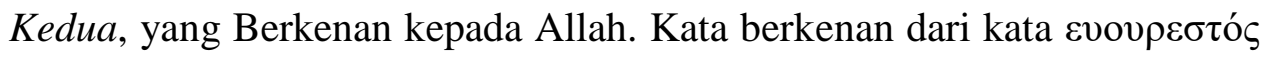
(euarestos) merupakan kata sifat neuter tunggal nominatif tidak bertingkat, selalu berkenaan dengan hal yang berkenan kepada Allah. Paulus memberikan penjelasan bahwa yang baik bukanlah asas abstrak, tetapi menyatakan diri dalam pergaulan antara seorang percaya dengan Allah. Pergaulan yang menuntut

${ }^{58}$ J. Verkuyl, Etika Kristen Bagian Umum (Jakarta: BPK Gunung Mulia, 1991), 84

${ }^{59}$ Poerwadarminta, Kamus Umum Bahasa Indonesia (Jakarta: Balai Pustaka, 1966), 81 
pengabdian sepenuhnya. ${ }^{60}$ Karena termasuk pengabdian maka orang-orang percaya harus berhenti menjadi serupa dengan dunia ini dan membiarkan dirinya berubah oleh pembaruan budi. Pembaruan dan perubahan ini harus dibuktikan dengan menyelidiki kehendak Allah yaitu: mana yang baik, berkenan kepada Allah dan sempurna. ${ }^{61}$ Dari sisi arti kata, kenan-berkenan, memiliki arti merasa senang (suka, sudi, setuju), dengan suka hati. ${ }^{62}$

Dapat disimpulkan bahwa hidup bergaul dengan Allah atau hidup oleh Roh menolong orang percaya memiliki kepekaan untuk menguji apakah hidupnya diperkenan (dijadikan berkenan, disukai dan disetujui) Tuhan atau tidak. Apa yang dikenan atau dikehendaki Allah adalah segala sesuatu yang sesuai dengan standar moral yang ditetapkan oleh Tuhan. Standar tersebut adalah gambar Allah. Segala sesuatu yang kehilangan kemuliaan Allah adalah dosa (Rm. 3: 23). 1 Korintus 10:31 menegaskan bahwa: "Jika engkau makan atau jika engkau minum, atau jika engkau melakukan sesuatu yang lain, lakukanlah semuanya itu untuk kemuliaan Allah." Standar moral yang benar adalah kelakuan yang sesuai dengan kehendak Tuhan dan memuliakan kemuliaan-Nya. ${ }^{63}$

Ketiga, yang Sempurna. Kata sempurna diterjemahkan dari $\tau \dot{\lambda} \lambda \varepsilon i o \varsigma$ (teleios), kata sifat normal nominatif neuter tunggal tidak bertingkat. Artinya: sempurna, lengkap, dewasa. Kata-kata yang sempurna merujuk pada Markus 12: 30, "Kasihilah Tuhan, Allahmu, dengan segenap hatimu dan dengan segenap akal budimu dan dengan segenap kekuatanmu." Perkataan sempurna menentukan arti yang baik dan juga arti yang berkenan. Hal yang baik dan yang berkenan bukan sesuatu yang dapat dijangkau manusia. Atau dapat dianggap telah terlaksana. Markus 10: 20, mengisahkan tentang orang muda yang ingin mengikut Tuhan Yesus. Segala yang ada dalam hukum Taurat sudah dilaksanakan. Dilihat dari tanggapan Yesus bahwa menurut ukuran-Nya, apa yang baik itu belum sempurna. Matius 19: 21 menunjukkan tanggapan Yesus: "Kata Yesus kepadanya: "Jikalau engkau hendak sempurna, pergilah, juallah segala milikmu dan berikanlah itu kepada orang-orang miskin, maka engkau akan beroleh harta di sorga, kemudian datanglah ke mari dan ikutlah Aku."

${ }^{60}$ End, Tafsir Alkitab Surat Roma, 660

${ }^{61}$ Everett T. Pfeiffer, Charles F., Harrison, The Wyclife Bible CommentaryPerjanjian Baru, vol 3. (Malang: Gandum Mas, 2013), 754

${ }_{62}$ Poerwadarminta, Kamus Umum Bahasa Indonesia, 562

${ }^{63}$ Heri Gunawan, Pendidikan Karakter Konsep Dan Implementasi (Bandung: Penerbit Alfabeta, 2014), 33 


\section{Fidei: Jurnal Teologi Sistematika dan Praktika, Vol. 4, No. 1, Juni 2021}

Sempurna adalah suatu keadaan utuh. Dari contoh peristiwa orang muda di atas, hanya satu yang mengurangi kesempurnaannya. Keterikatan dan kecintaan akan uang membuat ketaatannya melakukan semua hukum Taurat (yang baik dan berkenan kepada Allah), dalam ukuran Tuhan menjadi tidak sempurna. Kesempurnaan menuntut kerelaan hati menyerahkan segala sesuatu kepada Tuhan. Kesimpulannya adalah Pembaruan budi seperti nampak dalam Roma 12: 2 menandai pertobatan Kristen. Orang-orang percaya diperlengkapi dengan daya tanggap yang lebih tajam dari sebelumnya, yakni dapat membedakan manakah kehendak Allah, apa yang baik, yang berkenan kepada Allah, dan yang sempurna.

\section{Kontekstualisasi Roma 12:2 dalam Dunia Digital}

Kontekstualisasi adalah usaha menempatkan sesuatu dalam konteksnya. Dalam hal ini adalah menempatkan Roma 12: 2 dalam konteks keniscayaan dunia digital. Ada empat hal praktis yang dapat diterapkan orang percaya dalam bermedia sosial. Pertama, jangan serupa dengan dunia, pergunakan pertimbangan moral dalam bermedia sosial. Banjirnya informasi dan juga kebebasan mengaktualisasi diri di zaman modern nyaris tidak terbendung. Semua orang tanpa memandang jender, status, serta usia, terpapar dunia digital. Orang percaya harus menggunakan standar moral Tuhan yaitu senantiasa mengarah pada kekudusan. ${ }^{64}$ Dalam membuat dan mengunggah konten di media sosial harus beretika. Tidak menyebarkan pornografi dan berita hoax dan hal-hal yang melanggar kekudusan. ${ }^{65}$ Kebebasan yang dimiliki seorang Kristen bukan kebebasan tanpa batas. Panduan hidup dan standar moral serta etika Kristen adalah Alkitab untuk semua bagian hidupnya. Termasuk dalam menggunakan media sosial.

Kedua, berubah oleh pembaruan budi, pergunakan pertimbangan mental. ${ }^{66}$ Orang Kristen memercayai bahwa dirinya dicipta segambar dan serupa dengan Allah (Kej.1:26). Tetapi ada juga yang meragukan dirinya secitra dengan Allah sehingga perlu personal branding (pencitraan diri), seperti dikejar oleh orang

${ }^{64}$ Susanto Dwiraharjo, "Persembahan Yang Hidup Sebagai Buah Dari Pembenaran Oleh Iman Menurut Roma 12: 1-2," Prudentia: Jurnal Teologi dan Pendidikan Kristiani 1, no. 1 (2018): 1-24.

${ }^{65}$ Rinna Rachmatika et al., "Sosialisasi Internet Sehat Dan Etika Bermedia Sosial Untuk Pkk Griya Indah Serpong," Jamaika: Jurnal Abdi Masyarakat 1, no. 1 (2020): 56-62.

${ }^{66}$ Tony Salurante, Dyulius Th Bilo, and David Kristanto, "Transformasi Komunitas Misi: Gereja Sebagai Ciptaan Baru Dalam Roh Kudus," Kurios (Jurnal Teologi dan Pendidikan Agama Kristen) 7, no. 1 (2021): 136-148. 
dunia. Ketika berada di dunia maya melupakan statusnya sebagai anak Allah yang sudah ditebus dan dibarui budinya. Seorang yang dibarui budinya dan dipulihkan gambar dirinya tidak perlu mencitrakan diri dengan cara yang salah. ${ }^{67}$ Ia akan menguji apakah sesuatu atau perilaku itu sesuai dengan kehendak Allah atau tidak. Orang yang belum dibarui pikirannya tidak sanggup membedakan kehendak Tuhan. Sebaliknya, orang yang menyerahkan tubuhnya kepada Tuhan, pikirannya dibarui dapat mengerti kehendak tanpa ditolong orang lain. Dapat dengan sendirinya menguji apa yang seharusnya dilakukan atau tidak. Orang Kristen yang yakin akan penebusan Kristus atas hidupnya dipulihkan gambar dirinya. Tidak perlu mengejar sedemikian rupa dengan menggunakan media sosial untuk menunjukkan siapa dirinya. Apalagi menabrak semua etika Kristen yang dipaparkan Paulus dalam Roma 12:2.

Ketiga, perubahan motivasi. Orang percaya menjadikan apa yang baik, berkenan dan sempurna sebagai motivasi dalam bermedia sosial. Orang bermedia sosial didorong oleh kebutuhan psikologis dan emosi. ${ }^{68}$ Pelaku media sosial dapat didorong oleh motivasi cinta, kompetensi, harga diri, dan kebutuhan mencari identitas. ${ }^{69}$ Manusia memang berada dalam proses pencarian tidak berkesudahan. Proses pencarian ini tidak dikendalikan oleh naluri, melainkan oleh kemampuan-kemampuan psikis manusia. ${ }^{70}$ Dalam perjuangan ini orang percaya menemukan dirinya sebagai makhluk yang bebas. Kebebasan itu dialami sebagai sebuah kesadaran diri yang meneguhkan sekaligus menuntut untuk berbuat sesuai hati nuraninya. Tentu saja hati nurani yang dikembangkan dalam terang iman kristiani.

Keempat, pertimbangan etika. ${ }^{71}$ Dalam mengaktualisasikan dirinya di dunia digital, apa yang tertulis dalam Roma 12:2 kini harus benar-benar menjadi etika dan aturan berperilaku bagi orang percaya. ${ }^{72}$ Kecenderungan orang

${ }^{67}$ Kevin Tony Rey, "Pembelajaran Dengan Sistem Konstruktivistik Sebagai Usaha Mewujudkan Aktualisasi Diri Yang Memiliki Gambar Dan Rupa Allah," Harvester: Jurnal Teologi dan Kepemimpinan Kristen 4, no. 1 (2019): 22-35.

${ }^{68}$ Asfira Rachmad Rinata and Sulih Indra Dewi, "Fanatisme Penggemar Kpop Dalam Bermedia Sosial Di Instagram,” Interaksi: Jurnal Ilmu Komunikasi 8, no. 2 (2019): 13-23.

${ }^{69}$ Salshabila Putri Persada et al., "Fenomena Perilaku Cyberbullying Di Dalam Jejaring Sosial Twitter," Interaksi Online 3, no. 1 (2014).

${ }^{70}$ Opi Ayu Velina and Maulana Rezi Ramadhana, "Pengaruh Motivasi Pengguna Media Sosial Terhadap Perilaku Adiksi (Studi Kasus Pada Mahasiswa Telkom University Jurusan Ilmu Komunikasi Angkatan 2018)," eProceedings of Management 6, no. 3 (2019).

${ }^{71}$ Ardian Setio Utomo and Diyah Ayu Karunianingsih, "Etika Komunikasi Publik Bagi Humas Pemerintah Dalam Bermedia Sosial," Jurnal Heritage 8, no. 2 (2020): 127-144.

${ }^{72}$ B James et al., "Mempersiapkan Sekolah Minggu Dewasa (Pra Remaja) Generasi Milenial Kristen Dengan Menggunakan Teori Kebutuhan Abraham Maslow" (n.d.), 1 
menjadi tidak terkontrol ketika berada di dunia maya. Etika sering dikesampingkan asalkan apa yang menjadi motivasinya tercapai. Tidak memertimbangkan apakah konten unggahannya menabrak etika. Pada waktu mengunggah gagasan dan perasaannya, orang percaya harus benar-benar selektif dalam memilih kata, gambar, video, yang tidak melanggar etika. Orang percaya tidak serupa dengan dunia walaupun masih tinggal di dunia. Sekalipun dorongan hati ingin seperti orang-orang di sekitarnya yang dengan bebas mencoba mengaktualisasikan diri sehingga menabrak semua etika. Kristen yang dewasa tahu memilih dan melakukan yang baik, yang berkenan kepada Allah dan yang sempurna.

\section{Simpulan}

Dari hasil uraian di atas dapat ditarik kesimpulan bahwa kontekstualisasi Roma 12:2 dalam dunia digital adalah: Pertama: menjadi pertimbangan moral dalam bermedia sosial yaitu tidak serupa dengan dunia. Kedua, sebagai pertimbangan mental. Orang Kristen memercayai bahwa dirinya dicipta segambar dan serupa dengan Allah. Sebagai orang yang telah mengalami pembaruan budi tidak perlu mencitrakan diri (personal branding) dengan cara yang salah dalam memenuhkan kebutuhan aktualisasi diri. Ketiga, mendorong perubahan motivasi dalam bermedia sosial. Orang percaya menjadikan apa yang baik, berkenan dan sempurna sebagai motivasi dalam bermedia sosial. Keempat, mejadi pertimbangan etika. Dalam mengaktualisasikan dirinya di dunia digital, apa yang tertulis dalam Roma 12:2 kini harus benar-benar menjadi etika dan aturan berperilaku bagi orang percaya. Dalam kaitannya dengan teori Hierarki Kebutuhan Maslow, manusia juga berusaha memenuhi kebutuhan-kebutuhannya melalui media sosial. Dengan kata lain manusia tidak bisa dilepaskan begitu saja dari aktivitas dunia digital. Roma 12: 2 memberi batasan jelas moral dan etika Kristen yaitu tidak menjadi serupa dengan dunia karena telah dibarui akal budinya sehingga dapat membedakan mana kehendak Allah, apa yang baik, yang berkenan, dan yang sempurna. Orang Kristen tinggal dalam sistem dunia tetapi tidak boleh larut dalam sistem dunia ini.

\section{Daftar Pustaka}

Adiarsi, Gracia Rachmi, Yolanda Stellarosa, and Martha Warta Silaban. "Literasi Media Internet Di Kalangan Mahasiswa." Humaniora 6, no. 4 (2015).

Allasso, Elisha Orcarus, and others. "Aktualisasi Diri Ki Seno Nugroho: 
Tinjauan Pemenuhan Kebutuhan Dalam Teori Motivasi Abraham H. Maslow.” Institut Seni Indonesia Yogyakarta, 2016.

Alwisol. Psikologi Kepribadian. Malang: Penerbitan Universitas Muhammadiyah, 2016.

Ardana, Nurni Amiroh Dwi Isma, and Budi Purwoko. "Studi Kepustakaan

Penerapan Konseling Naratif Dalam Lingkup Pendidikan." Jurnal BK Unesa 8, no. 2 (2018).

Astuti, Yanti Dwi. "Peperangan Generasi Digital Natives Melawan Digital Hoax Melalui Kompetisi Kreatif." Informasi 47, no. 2 (2017).

Badai, Kristian, Kaleb Djeremod, and Frets Keriapy. "Penginjilan Sebagai Upaya Meneguhkan Keyakinan Keselamatan Anak." Harvester: Jurnal Teologi dan Kepemimpinan Kristen 5, no. 2 (2020).

Barclay, William. Pemahaman Alkitab Setiap Hari Surat Roma. Cetakan Ke. Jakarta: BPK Gunung Mulia, 2003.

Boeree, C.George. Personality Theories, Melacak Kepribadian Anda Bersama Psikolog Dunia. Yogyakarta: Prismasophie, 2004.

Darmawan, Agus, Muhyani Muhyani, and Salati Asmahasanah. "Hubungan Pola Asuh Orang Tua Dan Guru Dengan Penyalahgunaan Media Sosial Di Man 1 Kota Bogor." e-Jurnal Mitra Pendidikan 3, no. 11 (2019).

Darmayanti, Kusumasari Kartika Hima, Farida Kurniawati, and Dominikus David Biondi Situmorang. "Bullying Di Sekolah: Pengertian, Dampak, Pembagian Dan Cara Menanggulanginya." Pedagogia 17, no. 1 (2019).

Digital, Kominfo Siber Kreasi Literasi. Media Sosial Pdf. Jakarta, n.d.

Dominggus, Dicky. "Efektivitas Pelaksanaan Ibadah Daring Ditinjau Dari Roma

12: 1-2." Sanctum Domine: Jurnal Teologi 10, no. 1 (2020).

Dwiraharjo, Susanto. "Persembahan Yang Hidup Sebagai Buah Dari Pembenaran Oleh Iman Menurut Roma 12: 1-2.” Prudentia: Jurnal Teologi dan Pendidikan Kristiani 1, no. 1 (2018).

End, Th.van den. Tafsir Alkitab Surat Roma. Jakarta: BPK Gunung Mulia, 2003. Estiyani, Rizka, Lisnawati Ruhaena, and others. "Ekspresi Diri Melalui Media

Sosial Dan Maknanya Pada Remaja SMP." Universitas Muhammadiyah Surakarta, 2018.

Felita, Pamela, Christine Siahaja, Vania Wijaya, Gracia Melisa, Marcella Chandra, and Rayini Dahesihsari. "Pemakaian Media Sosial Dan Self Concept Pada Remaja." Manasa-old 5, no. 1 (2016).

Gunawan, Heri. Pendidikan Karakter Konsep Dan Implementasi. Bandung: Penerbit Alfabeta, 2014. 
138 Fidei: Jurnal Teologi Sistematika dan Praktika, Vol. 4, No. 1, Juni 2021

Guthrie, Donald. Teologi Perjanjian Baru 1. 1st ed. Jakarta: PT BPK Gunung Mulia, 1991.

Jaffray, R.A. Tafsiran Surat Roma. Bandung: Yayasan Kalam Hidup, 2007.

James, B, G Gustaf, E Erik, and others. "Mempersiapkan Sekolah Minggu

Dewasa (Pra Remaja) Generasi Milenial Kristen Dengan Menggunakan Teori Kebutuhan Abraham Maslow" (n.d.).

Nahar, Novi Irwan. "Penerapan Teori Belajar Behavioristik Dalam Proses Pembelajaran." Nusantara: Jurnal Ilmu Pengetahuan Sosial 1, no. 1 (2016).

Nasional, Departemen pendidikan. Kamus Besar Bahasa Indonesia Pusat Bahasa,Ed.IV. IV. Jakarta: PT. Gramedia Pustaka Utama, 2008.

Nazir, M. Metode Penelitian. Bogor: Ghalia Indonesia, 2009.

Niftrik, G.C van, Boland, B.J. Dogmatika Masa Kini. Jakarta: BPK Gunung Mulia, 2014.

Persada, Salshabila Putri, Djoko Setyabudi, Turnomo Rahardjo, and Nurrist Surayya Ulfa. "Fenomena Perilaku Cyberbullying Di Dalam Jejaring Sosial Twitter." Interaksi Online 3, no. 1 (2014).

Pfeiffer, Charles F., Harrison, Everett T. The Wyclife Bible CommentaryPerjanjian Baru. Vol 3. Malang: Gandum Mas, 2013.

Pilendia, Dwitri. "Pemanfaatan Adobe Flash Sebagai Dasar Pengembangan Bahan Ajar Fisika: Studi Literatur." Jurnal Tunas Pendidikan 2, no. 2 (2020).

Poerwadarminta. Kamus Umum Bahasa Indonesia. Jakarta: Balai Pustaka, 1966. Pohan, Fiona Almira, and Hairul Anwar Dalimunthe. "Hubungan Intimate Friendship Dengan Self-Disclosure Pada Mahasiswa Psikologi Pengguna Media Sosial Facebook." Jurnal Diversita 3, no. 2 (2017).

Rachmatika, Rinna, Kecitaan Harefa, Perani Rosyani, Ny Ayni Suwarni Herry, and Joko Priambodo. "Sosialisasi Internet Sehat Dan Etika Bermedia Sosial Untuk Pkk Griya Indah Serpong.” Jamaika: Jurnal Abdi Masyarakat 1, no. 1 (2020).

Rahadi, Dedi Rianto. "Perilaku Pengguna Dan Informasi Hoax Di Media Sosial." Jurnal Manajemen dan Kewirausahaan 5, no. 1 (2017).

Rastati, Ranny. "Media Literasi Bagi Digital Natives: Perspektif Generasi Z Di Jakarta.” Kwangsan 6, no. 1 (2018).

Rey, Kevin Tony. "Pembelajaran Dengan Sistem Konstruktivistik Sebagai Usaha Mewujudkan Aktualisasi Diri Yang Memiliki Gambar Dan Rupa Allah." Harvester: Jurnal Teologi dan Kepemimpinan Kristen 4, no. 1 
(2019).

Rifauddin, Machsun. "Fenomena Cyberbullying Pada Remaja." Jurnal Ilmu Perpustakaan, Informasi, dan Kearsipan Khizanah Al-Hikmah 4, no. 1 (2016).

Rinata, Asfira Rachmad, and Sulih Indra Dewi. "Fanatisme Penggemar Kpop Dalam Bermedia Sosial Di Instagram.” Interaksi: Jurnal Ilmu Komunikasi 8, no. 2 (2019).

Roesnilam Syafitri, Evita, and Wiryo Nuryono. "Studi Kepustakaan Teori Konseling 'Dialectical Behavior Therapy."' Jurnal BK UNESA 11, no. 1 (2020).

Ronda, Daniel. "Kepemimpinan Kristen Di Era Disrupsi Teknologi." Evangelikal: Jurnal Teologi Injili dan Pembinaan Warga Jemaat (2019).

Rorong, Novita Indriani, and Dicky Dominggus. "Budaya Kekerasan Dalam Media Elektronik Ditinjau Dari Sudut Pandang Etika Kristen." FIDEI: Jurnal Teologi Sistematika dan Praktika 3, no. 1 (2020).

Salurante, Tony, Dyulius Th Bilo, and David Kristanto. "Transformasi Komunitas Misi: Gereja Sebagai Ciptaan Baru Dalam Roh Kudus." KURIOS (Jurnal Teologi dan Pendidikan Agama Kristen) 7, no. 1 (2021).

Sanyata, Sigit. "Teori Dan Aplikasi Pendekatan Behavioristik Dalam Konseling." Jurnal Paradigma 14, no. 7 (2012).

Setiawan, Topan, Yuni Kurniawati, and Edy Saputro. "Komunikasi Krisis Di Era Digital.” Jurnal Ekonomi, Sosial \& Humaniora 1, no. 02 (2019).

Sukrillah, Ahmad, Ike Atikah Ratnamulyani, and Ali Alamsyah Kusumadinata.

"Pemanfaatan Media Sosial Melalui Whatsapp Group Fei Sebagai Sarana Komunikasi." Jurnal Komunikatio 3, no. 2 (2018).

Sumiwi, Asih Rachmani Endang. "Pembaharuan Pikiran Pengikut Kristus Menurut Roma 12: 2." Jurnal Teologi Berita Hidup 1, no. 1 (2018).

Sunarsi, Denok. "Analisis Motivasi Kerja Tenaga Pendidik Sukarela Pada Pusat Kegiatan Belajar Masyarakat (PKBM) Bimasda Kota Tangerang Selatan." Kreatif: Jurnal Ilmiah Prodi Manajemen Universitas Pamulang 6, no. 2 (2018).

Supratman, Lucy Pujasari. "Penggunaan Media Sosial Oleh Digital Native" (2018).

Susilo, Budi. "Pemasaran Digital: Segmentasi Demografi Pengguna Media Sosial Di Kota Pontianak." Jurnal Eksplora Informatika 8, no. 1 (2018).

Sutanto, Hasan. Perjanjian Baru Interlinear Yunani-Indonesia Dan Konkordansi Perjanian Baru (PBIK). I. Jakarta: LAI, 2006. 
Tani, Deisti Glorya Christina, and Nani Mediatati. "Tingkat Kesadaran Hukum Peserta Didik Dalam Menggunakan Media Sosial." Journal of Education Technology 4, no. 1 (2020).

Tresnawati, Yuni, and Kurniawan Prasetyo. "Pemetaan Konten Promosi Digital Bisnis Kuliner Kika's Catering Di Media Sosial.” PRofesi Humas 3, no. 1 (2018).

Utomo, Ardian Setio, and Diyah Ayu Karunianingsih. "Etika Komunikasi Publik Bagi Humas Pemerintah Dalam Bermedia Sosial." Jurnal Heritage 8, no. 2 (2020).

Velina, Opi Ayu, and Maulana Rezi Ramadhana. "Pengaruh Motivasi Pengguna Media Sosial Terhadap Perilaku Adiksi (Studi Kasus Pada Mahasiswa Telkom University Jurusan Ilmu Komunikasi Angkatan 2018)." eProceedings of Management 6, no. 3 (2019).

Verkuyl, J. Etika Kristen Bagian Umum. Jakarta: BPK Gunung Mulia, 1991.

Widiastuti, Nela. "Berita Viral Di Media Sosial Sebagai Sumber Informasi Media Massa Konvensional." Journal Digital Media \& Relationship 1, no. 1 (2019).

Wijaya, E. Chrisna. "Kekhasan Eskatologi Paulus." FIDEI: Jurnal Teologi Sistematika dan Praktika 1, no. 1 (2018).

Wijaya, Hengki, and I Putu Ayub Darmawan. "Optimalisasi Superego Dalam Teori Psikoanalisis Sigmund Freud Untuk Pendidikan Karakter” (2019).

Yulia, Irla. "Optimalisasi Penggunaan Media Sosial Dalam Pemasaran Sosial Dan Komunikasi Perubahan Perilaku (Suatu Pendekatan Studi Literature Review)." HEARTY: Jurnal Kesehatan Masyarakat 6, no. 2 (2018).

Zaluchu, Sonny Eli.“Pola Hermenetik Sastra Hikmat Orang Ibrani." Evangelikal 3,no.1(2019).https://journal.sttsimpson.ac.id/index.php/EJTI/article/view/1 23.

Alkitab Penuntun Hidup Berkelimpahan. Malang: Gandum Mas dan LAI, 2009. 